PRZEGLĄD BIBLIOTECZNY 2019 z. 4 PL ISSN 0033-202X

\author{
ADAM JACHIMCZYK \\ Wydział Dziennikarstwa, Informacji i Bibliologii \\ Uniwersytet Warszawski \\ e-mail: a.jachimczyk@uw.edu.pl \\ OBCID: 0000-0003-2917-6926
}

\title{
OCHRONA ZNAKÓW TOWAROWYCH PRZEZ BIBLIOTEKI W ŚWIETLE ZAWARTOŚCI BAZY DANYCH TMview
}

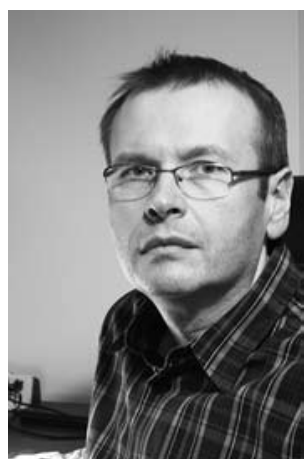

Adam Jachimczyk, dr, adiunkt w Katedrze Bibliografii i Dokumentacji na Wydziale Dziennikarstwa, Informacji i Bibliologii Uniwersytetu Warszawskiego. Zainteresowania naukowe: zastosowanie technologii informatycznej w działalności informacyjnej. Opublikował m.in.: Internetowe zasoby bibliograficzne instytutów badawczych oraz jednostek Polskiej Akademii Nauk (2016). W: J. Franke i J. Woźniak-Kasperek (red.) Bibliografia: historia, teoria, praktyka: praca zbiorowa. Warszawa: SBP; razem z M. Chrapek i Z. Chrapkiem: Web directories: selected features and their impact on directory quality (2016). Program-Electronic Library and Information Systems, vol. 50 no 3; czy Otwarte dane badawcze. Casus polskich instytutów badawczych (2015). Zagadnienia Naukoznawstwa, nr 4.

SŁOWA KLUCZOWE: Biblioteki. TMview. Znaki towarowe.

ABSTRAKT: Teza/Cel artykułu - Celem artykułu jest przedstawienie aktywności europejskich bibliotek w zakresie rejestracji znaków towarowych. Metody badań - Analiza ilościowa objęła następujące zagadnienia: kraj, w którym dokonano zgłoszenia znaku towarowego, biblioteki z największą liczbą znaków zgłoszonych do rejestracji, rok zgłoszenia, status znaku, rodzaj biblioteki, rodzaj i typ znaku towarowego. Źródłem danych była baza TMview zarządzana przez Urząd Unii Europejskiej ds. Własności Intelektualnej. Wyniki i wnioski - Ogółem zidentyfikowano 380 zgłoszeń pochodzących z 24 krajów. Próbę rejestracji znaku podjęło 166 bibliotek. Tylko w 14 krajach biblioteki narodowe dokonały takiego zgłoszenia, biblioteki publiczne zrobiły to w 22 krajach, a biblioteki naukowe w 16 . Bazy 
danych znaków towarowych mogą być wykorzystywane do identyfikowania produktów i usług oferowanych bibliotekom, jak również pokazywać różne formy aktywności związanej z promowaniem książki i czytelnictwa na określonym obszarze.

\section{WSTĘP}

W literaturze przedmiotu działalność bibliotek stosunkowo rzadko jest rozpatrywana w kontekście zarejestrowanych przez nie znaków towarowych. Ten obszar, związany z ochroną własności intelektualnej, powszechnie raczej wiąże się z działalnością przedsiębiorstw produkcyjno-usługowych, mniej z działaniami podejmowanymi przez biblioteki. Biblioteki są postrzegane raczej jako miejsca dostępu do baz danych rejestrujących zgłoszenia patentowe czy znaki towarowe z uwagi na specjalnie przeszkolony personel potrafiący je efektywnie przeszukiwać na zlecenie użytkowników (Zhang, 2009; Sneed, 2000; Irvin, 2018).

Badacze zajmujący się bibliotekami niejednokrotnie podejmowali problem kształtowania przez nie wizerunku wśród swoich użytkowników. Wobec malejącej liczby czytelników, rozwoju łatwo dostępnych cyfrowych źródeł informacji (np. księgarni sprzedających tanie książki cyfrowe), biblioteki muszą podejmować pewne działania, które pokażą je jako miejsce dostępu do różnorodnych źródeł informacji, czy alternatywnego źródła rozrywki (Grabowska, 2011; Hood \& Henderson, 2005; Hariff \& Rowley, 2011). Te starania (określane mianem brandingu) mają zaprzeczyć dość powszechnemu negatywnemu stereotypowi placówki bibliotecznej jako stosunkowo mało przyjaznego miejsca, w którym w zasadzie nic się nie dzieje (Wojciechowski, 2006).

Częścią tych działań jest kształtowanie marki bibliotecznej, czyli znaków, terminów, symboli czy rysunków, które identyfikują bibliotekę i/lub oferowane przez nią produkty i usługi biblioteczne (Leksykon zarządzania i marketingu w bibliotekoznawstwie, 2019). Marka nie tylko zwiększa rozpoznawalność biblioteki wśród jej użytkowników, ale także powinna budować pozytywne skojarzenia $\mathrm{z}$ oferowanymi przez nią produktami lub usługami (Wójcik, 2019).

W ramach kształtowania marki tworzy się np. system identyfikacji wizualnej biblioteki, który obejmuje m.in. nazwę placówki, jej logo, kolorystykę, materiały informacyjne, stronę WWW (Wójcik, 2019; Curyło, 2018; Augustyn \& Kawecka, 2011). Roughen, badając kilka amerykańskich bibliotek, ustalił, że tzw. branding najczęściej właśnie obejmował zmianę lub skrócenie nazwy biblioteki, opracowanie nowego logo, zmianę bibliotecznej witryny WWW, czy przygotowanie nowych materiałów promocyjnych (Roughen, 2016). Zainteresowanie badaczy budzi np. forma logo stosowanego przez biblioteki (Włoszczyńska, 2008; Fluda-Krokos, 2017; Kruszewski, 2011), które wg Jędrzeja Leśniewskiego jest w zasadzie je- 
dynym elementem „... świadomie kształtowanej tożsamości wizualnej” (Leśniewski, 2014). Tak ukształtowana marka może podlegać ochronie prawnej i niektóre biblioteki podejmują starania na rzecz rejestracji znaków towarowych związanych z jej działalnością.

$\mathrm{W}$ polskim systemie ochrony własności intelektualnej pojęcie znaku towarowego zostało zdefiniowane $\mathrm{w}$ ustawie z dnia 30 czerwca 2000 r. Prawo własności przemysłowej. Jej znowelizowana wersja z dnia 20 lutego 2019 r. definiuje znak towarowy jako „....każde oznaczenie umożliwiające odróżnienie towarów jednego przedsiębiorstwa od towarów innego przedsiębiorstwa oraz możliwe do przedstawienia w rejestrze znaków towarowych w sposób pozwalający na ustalenie jednoznacznego i dokładnego przedmiotu udzielonej ochrony" (Ustawa z dnia 30 czerwca $2000 \mathrm{r}$. Prawo własności przemysłowej, b.d.). Znakiem towarowym może być wyraz, łącznie z nazwiskiem, rysunek, litera, cyfra, kolor, forma przestrzenna, w tym kształt towaru lub opakowania, a także dźwięk (Ustawa z dnia 30 czerwca 2000 r. Prawo własności przemysłowej, b.d.). Ale coraz częściej podejmowane są także próby rejestracji innych niestandardowych form znaków towarowych, np. zapachowych, smakowych, czy dotykowych (Mishra, 2008; Studziński, 2016).

Znak towarowy pełni kilka funkcji. Ryszard Skubisz zwraca uwagę na następujące: oznaczenie pochodzenia, funkcję jakościową i reklamową. Nabywca otrzymuje jasny przekaz, że towar lub usługa pochodzi od konkretnego przedsiębiorcy. Znak towarowy może też wskazywać potencjalnemu nabywcy na określone cechy użytkowe lub jakościowe produktu. Powinien też zachęcać do kupna produktu lub usługi (Skubisz, b.d.).

Organizacje, rejestrując znaki towarowe we właściwych urzędach ds. własności intelektualnej, kierują się różnymi motywami. Doceniają ich marketingowe znaczenie, rolę w lepszej identyfikacji określonego produktu czy usługi wśród wielu innych dostępnych na rynku. Starają się $\mathrm{w}$ ten sposób także chronić produkt przed nieuczciwą konkurencją ze strony innych podmiotów, np. w postaci wytworzenia imitacji produktu, ale znacznie gorszej jakości. Jest to też metoda sygnalizowania pewnych zmian, które zachodzą np. w strategii określonej korporacji (Castaldi, 2018; Flikkema, De Man, \& Castaldi, 2014).

\section{CEL ANALIZY}

Badacze, poza nielicznymi wyjątkami (Roughen, 2017), nie wykorzystują zbiorów informacji o zgłoszonych do rejestracji znakach towarowych jako jednego ze źródeł informacji do analiz dotyczących aktywności bibliotek. Dla porównania, specjaliści reprezentujący inne obszary nauki nie unikają wykorzystania tego typu źródeł informacji, np. do analiz związanych z historią gospodarczą (Newton, 2010; Mercer, 2010), badania po- 
ziomu innowacyjności wśród małych i średnich przedsiębiorstw (Flikkema i in., 2014), jak również analiz dotyczących innowacyjności w sektorze usług i marketingu (Millot, 2009).

W piśmiennictwie bibliologicznym brakuje odniesień do kwestii podejmowania przez biblioteki działań związanych z ochroną znaków towarowych. W związku z tym uzasadnione wydaje się zbadanie, czy i do jakiego stopnia europejskie biblioteki podejmują takie starania. W artykule, stosując analizę ilościowa, zbadano następujące zagadnienia:

1. Kraje, w których dokonano zgłoszenia rejestracyjnego znaku towarowego.

2. Biblioteki z największą liczbą zgłoszonych do rejestracji znaków towarowych.

3. Rok zgłoszenia znaku do rejestracji.

4. Status znaku. W bazie TMview wyróżniono kilka statusów znaków towarowych:

a) wygasły. Oznacza, że upłynął okres ochronny i określona organizacja nie zdecydowała się na jego przedłużenie.

b) zakończony. Ten status może oznaczać, że urząd odmówił rejestracji znaku, ewentualnie sama organizacja wycofała zgłoszenie rejestracyjne.

c) zarejestrowany. Znak towarowy posiada prawo ochronne.

d) zgłoszony. Status oznacza, że trwa procedura rejestracji znaku.

5. Rodzaj biblioteki. Wszystkie zidentyfikowane biblioteki przypisano do jednej z następujących grup: naukowe, narodowe, publiczne. W przypadku konsorcjów bibliotecznych wyróżniono wszystkie rodzaje bibliotek, które należą do danego konsorcjum.

6. Rodzaj znaku towarowego. W tej części analizy zastosowano typologię stosowaną w bazie TMview, która obejmuje 20 różnych rodzajów znaków towarowych (m.in. słowne, graficzne, dźwiękowe, hologramy, znaki trójwymiarowe, kombinowane). Niemniej jednak EUIPO zastrzega, że „W zależności od urzędu, pojęcie znaków graficznych może się nieco różnić: Jeżeli znak graficzny zawiera również nazwę (posiadanie nazwy jest charakterystyczne dla znaku słownego), niektóre urzędy sklasyfikują ten znak graficzny jako kombinowany znak towarowy" („Pomoc PL”, b.d.).

7. Typ znaku towarowego. Wszystkie znaki przypisano do jednej $\mathrm{z}$ dwóch kategorii:

a) znak o charakterze organizacyjnym, którego celem jest identyfikacja określonej jednostki;

b) znak produktowy, którego zadaniem jest informowanie o produktach i usługach oferowanych przez daną jednostkę. 


\section{KRYTERIA DOBORU MATERIAŁU DO ANALIZY}

Źródłem danych była baza TMview („,TMview”, b.d.) zarządzana przez Urząd Unii Europejskiej ds. Własności Intelektualnej (European Union Intellectual Property Office - EUIPO). Zawiera ona dane dotyczące znaków towarowych zarejestrowanych we wszystkich krajach Unii Europejskiej, jak również dane pochodzące z krajów współpracujących z EUIPO (np. Chile, Kanada, Szwajcaria, Stany Zjednoczone). Aktualizowana codziennie baza w dniu 26 października 2019 r. liczyła ponad 53 miliony rekordów.

W celu wybrania danych do analizy przeszukano bazę pod kątem znaków towarowych zgłoszonych do rejestracji przez biblioteki. Do formularza wyszukiwawczego w polu Zgłaszający (Applicant) wpisano słowo „biblioteka” w językach krajów należących do UE. Przy wyszukiwaniu zastosowano rozmycie 50\% w celu wyszukania jak największej liczby jednostek używających w nazwie słowa biblioteka.

Dane pobrano 7 maja 2019 r. W rezultacie wyszukiwania otrzymano dane dotyczące nie tylko samych placówek bibliotecznych, lecz także podmiotów, których nazwa zawiera słowo biblioteka. W analizie pominięto jednostki, które nie są bibliotekami, stowarzyszenia działające na rzecz bibliotek, czy przedsiębiorstwa obsługujące biblioteki, np. dostarczające oprogramowanie biblioteczne; uwzględniono natomiast konsorcja biblioteczne. Do analizy otrzymano zbiór liczący 380 rekordów. Badanie dotyczące rodzaju biblioteki, typu znaku towarowego przeprowadzono między majem a październikiem $2019 \mathrm{r}$.

Autor jest świadomy pewnych ograniczeń związanych z wyszukanym zbiorem danych. Przy tak skonstruowanym zapytaniu w zbiorze nie uwzględniono placówek bibliotecznych, które nie używają terminu biblioteka w nazwie. Niewiadomą pozostaje także kompletność bazy danych. Jak zaznacza organ odpowiedzialny za utrzymanie bazy TMview, może ona nie zawierać kompletu danych pochodzących z danego kraju.

Nie do końca także wiadomo, jak biblioteki rejestrują swoje znaki towarowe, czy same, czy za pośrednictwem organu nadzorującego. Jednostki administracji państwowej lub samorządowej niejednokrotnie rejestrują takie znaki, ale nie zawsze było możliwe ustalenie, czy dotyczą one określonej biblioteki, czy tylko promują np. usługi biblioteczne lub czytelnictwo.

\section{WYNIKI ANALIZY}

KRAJ ZGŁOSZENIA

Tabela 1 przedstawia liczbę zgłoszonych do rejestracji znaków towarowych w poszczególnych krajach oraz liczbę bibliotek, które złożyły taki wniosek. Ogółem zgłoszeń rejestracyjnych dokonywano w 24 krajach. 
Zdecydowanie dominuje Francja, gdzie zgłoszono do rejestracji blisko $19 \%$ ogółu analizowanych znaków. W bazie TMview nie zidentyfikowano natomiast żadnych wniosków z Cypru, Grecji, Luksemburga i Malty.

Liczba zgłoszonych do rejestracji znaków towarowych wg krajów

\begin{tabular}{|c|c|c|c|c|}
\hline Kraj & Liczba & $\%(n=380)$ & $\begin{array}{c}\text { Liczba } \\
\text { zgłaszających } \\
\text { bibliotek }\end{array}$ & $\%(n=166)$ \\
\hline Francja & 72 & 18,95 & 14 & 8,43 \\
\hline Niemcy & 35 & 9,21 & 14 & 8,43 \\
\hline Holandia & 34 & 8,95 & 18 & 10,84 \\
\hline Czechy & 33 & 8,68 & 10 & 6,02 \\
\hline Rumunia & 31 & 8,16 & 12 & 7,23 \\
\hline Wielka Brytania & 26 & 6,84 & 11 & 6,63 \\
\hline Hiszpania & 24 & 6,32 & 11 & 6,63 \\
\hline Włochy & 17 & 4,47 & 13 & 7,83 \\
\hline Litwa & 16 & 4,21 & 9 & 5,42 \\
\hline Szwecja & 16 & 4,21 & 8 & 4,82 \\
\hline Polska & 15 & 3,95 & 10 & 6,02 \\
\hline Słowenia & 15 & 3,95 & 5 & 3,01 \\
\hline Węgry & 12 & 3,16 & 7 & 4,22 \\
\hline Dania & 10 & 2,63 & 7 & 4,22 \\
\hline Bułgaria & 5 & 1,32 & 3 & 1,81 \\
\hline Estonia & 5 & 1,32 & 3 & 1,81 \\
\hline Łotwa & 4 & 1,05 & 2 & 1,20 \\
\hline Słowacja & 3 & 0,79 & 2 & 1,20 \\
\hline Portugalia & 2 & 0,53 & 2 & 1,20 \\
\hline Austria & 1 & 0,26 & 1 & 0,60 \\
\hline Belgia & 1 & 0,26 & 1 & 0,60 \\
\hline Chorwacja & 1 & 0,26 & 1 & 0,60 \\
\hline Finlandia & 1 & 0,26 & 1 & 0,60 \\
\hline Irlandia & 1 & 0,26 & 1 & 0,60 \\
\hline
\end{tabular}

Źródło: oprac. własne.

W sumie znaki towarowe zgłosiło do rejestracji 166 bibliotek, najwięcej z Francji, Niemiec i Holandii.

Z tabeli 2 (uwzględniono biblioteki, które zarejestrowały przynajmniej 5 znaków) wyłania się obraz najaktywniejszych bibliotek pod względem zgłoszonych do rejestracji znaków towarowych. Zdecydowanie przoduje Bibliothèque nationale de France, która zgłosiła ponad 10\% ogółu znaków spośród wszystkich zgłoszonych w krajach UE. W przypadku innych bibliotek odsetek ten nie przekracza 4. 
Biblioteki z największą liczbą zgłoszonych do rejestracji znaków towarowych

\begin{tabular}{|c|c|c|c|}
\hline Biblioteka & Kraj & Liczba & $\%(n=380)$ \\
\hline Bibliothèque nationale de France & Francja & 40 & 10,53 \\
\hline Bibliotheque publique d'information & Francja & 13 & 3,42 \\
\hline Koninklijke Bibliotheek & Holandia & 11 & 2,89 \\
\hline Národní knihovna České republiky & Czechy & 11 & 2,89 \\
\hline The British Library & $\begin{array}{l}\text { Wielka } \\
\text { Brytania }\end{array}$ & 9 & 2,37 \\
\hline Biblioteca Centrală Universitară „Lucian Blaga” & Rumunia & 8 & 2,11 \\
\hline Narodna in univerzitetna knjižnica & Słowenia & 8 & 2,11 \\
\hline $\begin{array}{l}\text { Lancashire County Library and Information } \\
\text { Service }\end{array}$ & $\begin{array}{l}\text { Wielka } \\
\text { Brytania }\end{array}$ & 7 & 1,84 \\
\hline Národní technická knihovna & Czechy & 7 & 1,84 \\
\hline Biblioteca Metropolitană București & Rumunia & 6 & 1,58 \\
\hline Fundacio Privada Biblioteca Josep Laporte & Hiszpania & 6 & 1,58 \\
\hline $\begin{array}{l}\text { Biblioteca Județeană „Alexandru Și Aristia } \\
\text { Aman” }\end{array}$ & Rumunia & 6 & 1,58 \\
\hline $\begin{array}{l}\text { Deutsche Zentralbibliothek für Medizin } \\
\text { (ZB MED) - Leibniz-Informationszentrum } \\
\text { Lebenswissenschaften - Stiftung des } \\
\text { öffentlichen Rechts }\end{array}$ & Niemcy & 6 & 1,58 \\
\hline $\begin{array}{l}\text { Land Rheinland-Pfalz } \\
\text { (Landesbibliothekszentrum Rheinland-Pfalz) }\end{array}$ & Niemcy & 6 & 1,58 \\
\hline Biblioteken vid Lunds universitet & Szwecja & 5 & 1,32 \\
\hline $\begin{array}{l}\text { Lietuvos Nacionalinė Martyno Mažvydo } \\
\text { Biblioteka }\end{array}$ & Litwa & 5 & 1,32 \\
\hline $\begin{array}{l}\text { Fundacion Amigos de la Biblioteca Nacional } \\
\text { de España }\end{array}$ & Hiszpania & 5 & 1,32 \\
\hline
\end{tabular}

Źródło: oprac. własne.

ROK ZGŁOSZENIA ZNAKU TOWAROWEGO

$Z$ analizy Wykresu 1 wynika, że stale rośnie liczba zgłoszeń rejestracyjnych znaków towarowych. Najstarsze zgłoszenie, jakie odnotowuje baza TMview, pochodzi z 1900 r., ale nie jest wykluczone, że to błąd w zapisie, gdyż znak został zarejestrowany dopiero w 1967 r. (Znak Nr 118696, 1967).

Mniej więcej do końca XX w. baza odnotowuje stosunkowo nieliczne zgłoszenia. Ich liczba rośnie dopiero w XXI w. Można ostrożnie zakładać, że wśród bibliotek zaczęła dojrzewać świadomość roli znaku w promocji biblioteki i oferowanych przez nią usług, a co za tym idzie konieczności jego ochrony. Wspominane wcześniej zastrzeżenia dotyczące kompletności bazy danych nie pozwalają jednak na wyciąganie dalej idących wniosków w tej mierze. 


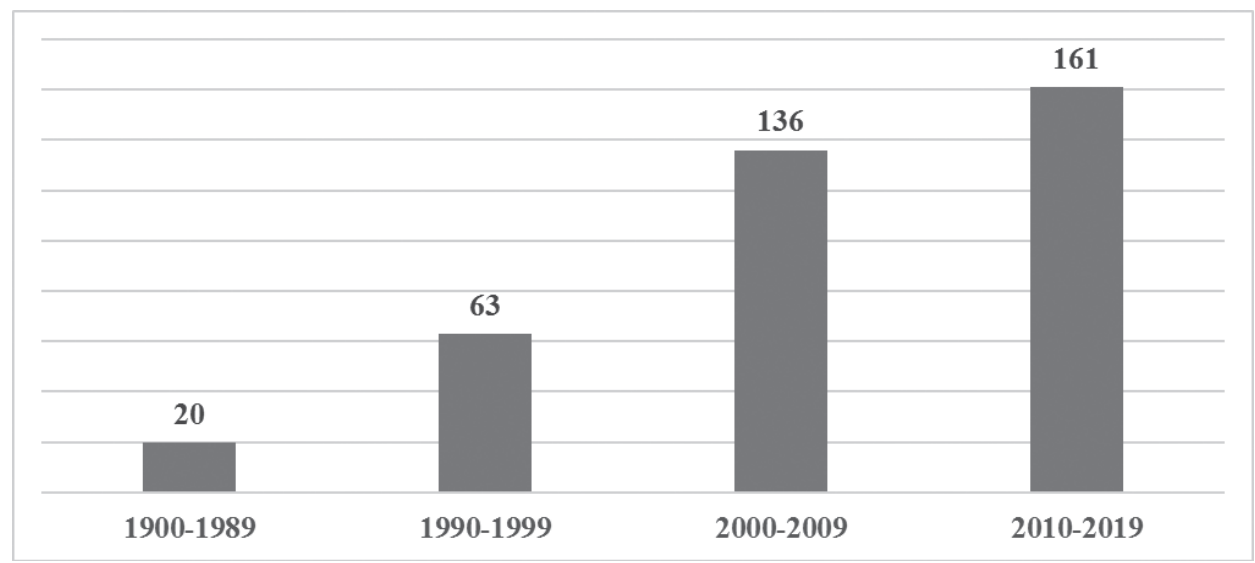

Wykres 1. Liczba znaków zgłoszonych do rejestracji przez biblioteki w latach 1900-2019

\section{STATUS ZNAKÓW}

Prawo ochronne na znak towarowy w większości krajów zazwyczaj jest przyznawane na okres dziesięciu lat. Można go przedłużyć o kolejne dziesięć lat pod warunkiem uiszczenia opłaty za dalszy okres ochronny (Trademark Registration, b.d.; Ustawa z dnia 30 czerwca 2000 r. Prawo własności przemysłowej, b.d.). W momencie przeprowadzania analizy ponad $60 \%$ znaków posiadało prawo ochronne, natomiast w przypadku prawie $29 \%$ takie prawo już wygasło. Grupie prawie $8 \%$ znaków odmówiono rejestracji.

Status zgłoszonych znaków towarowych

\begin{tabular}{|l|c|c|}
\hline Status & Liczba & $\mathbf{\%}$ \\
\hline zakończony & 28 & 7,37 \\
\hline wygasły & 109 & 28,68 \\
\hline zgłoszony & 11 & 2,89 \\
\hline zarejestrowany & 232 & 61,05 \\
\hline
\end{tabular}

Źródło: oprac. własne.

Ze statystyk wyłania się także zestawienie krajów, z których pochodzi największa liczba odrzuconych wniosków. $W$ tej dziedzinie największa liczba wniosków pochodzi z Czech (siedem), Litwy i Rumunii (po pięć) oraz Szwecji (cztery).

\section{RODZAJ BIBLIOTEKI}

Stosunkowo najwięcej znaków zgłosiły biblioteki publiczne. Zbliżoną liczbę znaków zgłosiły biblioteki narodowe i naukowe. Ta statystyka będzie wyglądała nieco inaczej, jeśli weźmiemy pod uwagę poszczególne kraje. We Francji Bibliothèque nationale de France zgłosiła do rejestracji 40 
znaków, a np. w Polsce Biblioteka Narodowa nie próbowała zarejestrować żadnego znaku towarowego. Także żadna z polskich bibliotek naukowych nie zgłosiła do rejestracji znaku towarowego. Na ten problem zwrócił już uwagę J. Leśniewski, który skierował ankietę do 60 polskich bibliotek uczelnianych. Spośród 17 bibliotek, które udzieliły odpowiedzi, żadna z nich nie zarejestrowała znaku towarowego (Leśniewski, 2014).

Polska, Holandia, Rumunia, Niemcy czy Włochy należą do grupy tych krajów, gdzie biblioteki publiczne dokonują stosunkowo dużej liczby zgłoszeń. W przypadku bibliotek naukowych w zakresie dokonywanych zgłoszeń aktywne są Niemcy, Hiszpania, Francja, czy Rumunia.

Zwraca uwagę, że spośród krajów należących do UE tylko w 14 biblioteki narodowe dokonały zgłoszenia rejestracyjnego. Dla porównania, biblioteki publiczne zrobily to w 22 krajach, a biblioteki naukowe w 16 .

Rodzaj biblioteki dokonującej rejestracji

\begin{tabular}{|l|c|}
\hline \multicolumn{1}{|c|}{ Rodzaj biblioteki } & $\begin{array}{c}\text { Liczba znaków zgłoszonych do } \\
\text { rejestracji }\end{array}$ \\
\hline narodowa & 99 \\
\hline narodowa; naukowa & 8 \\
\hline naukowa & 110 \\
\hline naukowa; publiczna & 3 \\
\hline publiczna & 160 \\
\hline
\end{tabular}

Źródło: oprac. własne.

\section{RODZAJ ZNAKU}

Jak wynika z tabeli 4, biblioteki raczej nie eksperymentują z rodzajami znaków towarowych. Przeważają znaki słowne, np. slogany promujące usługi biblioteczne. Nieco mniejszą grupę stanowią znaki, które zawierają elementy słowne i graficzne. Wprawdzie w bazie wyróżniono kategorię innych znaków towarowych, ale w zasadzie można ją na podstawie analizy danych przypisać do kategorii znaków łączących elementy graficzne ze słownymi.

Tabela 5

Rodzaj znaku towarowego

\begin{tabular}{|l|c|}
\hline \multicolumn{1}{|c|}{ Rodzaj znaku } & Liczba \\
\hline 3-D & 1 \\
\hline kombinowane (znaki słowno-graficzne) & 126 \\
\hline graficzne & 61 \\
\hline inne & 16 \\
\hline stylizowane znaki & 1 \\
\hline słowne & 175 \\
\hline
\end{tabular}

Źródło: oprac. własne. 
TYP ZNAKU TOWAROWEGO

Wszystkie znaki towarowe przypisano do jednej z dwóch kategorii: znaki identyfikujące określoną organizację oraz promujące produkt lub usługę oferowaną przez daną jednostkę.

Większa liczba zarejestrowanych znaków o charakterze produktowym nie powinna dziwić, gdyż biblioteki mogą rejestrować wiele znaków tego typu promując np. własną produkcję wydawniczą oferowane usługi, czy organizowane imprezy. Również nie powinien zaskakiwać wysoki odsetek znaków, w przypadku których biblioteki nie wystąpiły o przedłużenie okresu ochronnego. Na przykład, zmiana nazwy biblioteki, zaprzestanie kontynuacji pewnej usługi naturalnie nie uzasadnia potrzeby przedłużenia okresu ochronnego znaku. Nie znamy jednak dokładnych motywów, dlaczego jednostki nie przedłużyły ważności znaku na kolejny okres.

Tabela 6

Typy znaków towarowych wg ich statusu

\begin{tabular}{|c|c|}
\hline Organizacyjny & $\mathbf{1 5 1}$ \\
\hline- zakończony & 9 \\
\hline- wygasły & 40 \\
\hline- zgłoszony & 10 \\
\hline- zarejestrowany & 92 \\
\hline Produktowy & $\mathbf{2 2 9}$ \\
\hline- zakończony & 19 \\
\hline- wygasły & 69 \\
\hline- zgłoszony & 1 \\
\hline- zarejestrowany & 140 \\
\hline
\end{tabular}

Źródło: oprac. własne.

\section{PODSUMOWANIE}

Analiza nie zmierzała do zidentyfikowania motywów, którymi kierują się biblioteki rejestrując lub nie znaki towarowe. Na tle ogólnej liczby placówek liczba tych, które dokonują zgłoszeń jest wyjątkowo niska, ale należy pamiętać, że duża część bibliotek, zwłaszcza publicznych, może nie podejmować działań, które wymagają rejestracji związanych z nimi znaków. Ponadto niektóre inicjatywy bibliotek często mają efemeryczny charakter i podejmowanie $\mathrm{w}$ takich sytuacjach procedury rejestracji znaku może się wydawać pewną kosztowną ekstrawagancją. Koszt pierwszej rejestracji znaku w UPRP wynosi bowiem przynajmniej $450 \mathrm{zl}$, a przedłużenie okresu ochronnego na kolejny okres to koszt $400 \mathrm{zł}$ („Opłaty za ochronę Urząd Patentowy Rzeczypospolitej Polskiej”, b.d.; „Opłaty zgłoszeniowe - Urząd Patentowy Rzeczypospolitej Polskiej", b.d.). Niewątpliwie jednak w celu kształtowania i ochrony marki bibliotecznej biblioteki, które do tej 
pory nie rejestrowały swoich znaków towarowych, powinny rozważyć podjęcie takich kroków.

Inna kwestia może się też związać z pewną nieznajomością tego zagadnienia w środowisku bibliotekarzy lub przekonaniem, że znak towarowy (logo, slogan) bardziej przynależą do działalności komercyjnej. Część bibliotek może się też wstrzymywać z rejestracją znaku towarowego powodowana przekonaniem, że znakowi przysługuje już ochrona wynikająca $z$ obowiązującego prawa autorskiego. Jednak nie wszystkim znakom będzie przysługiwała ochrona z tego tytułu. Orzecznictwo sądów wskazuje np., że bardzo trudno uzyskać taką ochronę dla znaków słownych jednowyrazowych lub kilkuwyrazowych (Kępiński, 2015).

Bazy znaków towarowych mogą być cennym źródłem informacji w analizach związanych z działalnością bibliotek. Mogą być wykorzystywane do identyfikowania produktów i usług oferowanych bibliotekom, pokazywać różne formy aktywności związanej z promowaniem książki i czytelnictwa w danym państwie czy mieście. Mogą być też źródłem informacji o innowacyjnych usługach, które wdrażają placówki biblioteczne, jak również pokazywać ewolucję symboli graficznych związanych z systemem identyfikacji wizualnej biblioteki. Warto rozważyć analizę motywów, którymi kierują się biblioteki podejmując rejestrację znaku towarowego.

\section{BIBLIOGRAFIA}

Augustyn, Renata; Kawecka, Urszula (2011). System identyfikacji wizualnej biblioteki jako element komunikacji z czytelnikiem [online], Biuletyn EBIB, (5), s. 1-7 [dostęp: 11.11.2019]. Dostępne w WWW: <http://www.ebib.pl/images/stories/numery/123/123_ augustyn.pdf>.

Castaldi, Carolina (2018). To trademark or not to trademark: The case of the creative and cultural industries. Research Policy, 47(3), pp. 606-616. https://doi.org/10.1016/j.respol.2018.01.006.

Curyło, Monika (2018). System identyfikacji wizualnej jako element tożsamości biblioteki akademickiej. W: Biblioteka w chmurze czy chmury nad biblioteka, s. 35-53 [online], [dostęp: 11.11.2019]. Dostępny w WWW: <https://ruj.uj.edu.pl/xmlui/handle/item/71596? search-result=true\&query $=$ cury $\% C 5 \% 820+$ system \&current-scope=\&rpp=10\&sort_by$=$ score $\&$ order $=$ desc $>$.

Flikkema, Meindert; De Man, Ard-Pieter; Castaldi, Carolina. (2014). Are Trademark Counts a Valid Indicator of Innovation? Results of an In-Depth Study of New Benelux Trademarks Filed by SMEs. Industry and Innovation, 21(4), pp. 310-331. https://doi. org/10.1080/13662716.2014.934547.

Fluda-Krokos, Agnieszka (2017). Logo bibliotek akademickich jako element identyfikacji wizualnej. W: Інформаційний простір бібліотеки: Польсько-украйнський досвід: Матеріали міжнародної науково-практичної конференції, 18-19 травня 2017 року, Аьвів, Україна / Національний університет «Дьвівська політехніка», Науково- 
технічна бібліотека; за редакцією Р. Самотий ; [редколегія: А. Андрухів, Р. Самотий, H. Мосієнко, С. Палюх], s. 368-389 [online], [dostęp: 11.11.2019]. Dostępny w WWW: $<$ http://ena.lp.edu.ua/bitstream/ntb/42346/1/Inf-prostir-biblioteky_2018-368-389.pdf>.

Grabowska, Hanna (2011). Zarządzanie marką w bibliotece na przykładzie Biblioteki Uniwersyteckiej w Poznaniu [online], Zarzadzanie Biblioteka, (1), s. 111-122 [dostęp: 11.11.2019]. Dostępny w WWW: <https://czasopisma.bg.ug.edu.pl/index.php/ZB/article/view/1740>.

Hariff, Subnum, Rowley, Jennifer (2011). Branding of UK public libraries. Library Management, 32(4/5), pp. 346-360. https://doi.org/10.1108/01435121111132338.

Hood, David; Henderson, Kay (2005). Branding in the United Kingdom public library service. New Library World, 106(1/2), pp. 16-28. https://doi.org/10.1108/03074800510575320

Irvin, David (2018). The Patent Office in the Library. Public Services Quarterly, 14(4), pp. 392-398. https://doi.org/10.1080/15228959.2018.1487360.

Kępiński, Jakub (2015). Czy znak towarowy może być utworem? Ruch Prawniczy, Ekonomiczny i Socjologiczny, 77(2), s. 177. https://doi.org/10.14746/rpeis.2015.77.2.12.

Kruszewski, Tomasz (2011). Logo instytucji non profit - modele stosowane w bibliotekach. Biblioteka, 15(25), s. 231-244. https://doi.org/10.14746/b.2011.15.9.

Leśniewski, Jędrzej (2014). Znak towarowy jako narzędzie tworzenia wizerunku wybranych wydawnictw i bibliotek. W: IV Wrocławskie Spotkania Bibliotekarzy. Red. Danuta Dudziak, Mirosław Ziółek, s. 327-337 [online], [dostęp: 11.11.2019]. Dostępny w WWW: $<$ https://depot.ceon.pl/handle/123456789/5035>.

Mercer, John (2010). A mark of distinction: Branding and trade mark law in the UK from the 1860s. Business History, 52(1), pp. 17-42. https://doi.org/10.1080/00076790903281033.

Millot, Valentine. (2009). Trademarks as an Indicator of Product and Marketing Innovations (OECD Science, Technology and Industry Working Papers 6. https://doi. org/10.1787/224428874418.

Mishra, Neha (2008). Registration of Non-Traditional Trademarks [online]. Journal of Intellectual Property Rights, (13(1)), pp. 43-50 [dostęp: 11.11.2019]. Dostępny w WWW: $<$ https://papers.ssrn.com/sol3/papers.cfm?abstract_id=3147369>.

Newton, David (2010). Historical trademarks - A resource for business research. World Patent Information, 32(4), pp. 275-276. https://doi.org/10.1016/j.wpi.2010.05.004.

Opłaty za ochronę - Urząd Patentowy Rzeczypospolitej Polskiej [online], [dostęp: 2.11. 2019]. Dostępny w WWW: <https://www.uprp.pl/oplaty-za-ochrone-oraz-przedluzenie-prawa-ochronnego-na-znak-towarowy/Lead05,540,1763,4,index,pl,text/>.

Opłaty zgłoszeniowe - Urząd Patentowy Rzeczypospolitej Polskiej [online], [dostęp: 2.11.2019]. Dostępny w WWW: <https://www.uprp.pl/oplaty-zgloszeniowe/Lead05, $173,1755,4$,index,pl,text/>.

Patent Nr 118696. (1967) [online], [dostęp: 29.10.2019]. Dostępny w WWW: <https://www. tmdn.org/tmview/welcome\#>.

Pomoc PL. [online], [dostęp: 29.10.2019]. Dostępny w WWW: <https://www.tmdn.org/ website-framework/tmdsview/tmview/helpFiles/pl/help.html\#53>.

Roughen, Patrick (2016). System Branding in Three Public Libraries: Live Oak Public Libraries, Charlotte Mecklenberg Library, and Richland Library. Library Philosophy and Practice (e-Journal), (1442), p. 35.

Roughen, Patrick (2017). Ownership of Intellectual Property in the Library Complex [online], Library Philosophy and Practice (e-journal), (1635), pp. 1-23 [dostęp: 11.11.2019]. Dostępny w WWW: <https://digitalcommons.unl.edu/libphilprac/1635/>. 
Skubisz, Ryszard (b.d.). Znaki towarowe. Ewolucja przedmiotu ochrony prawnej [online], [dostęp: 11.11.2019]. Dostępny w WWW: <https://www.uprp.pl/uprp/_gAllery/15/50/ 15507/Znaki_towarowe._Ewolucja_przedmiotu_ochrony_prawnej_-_prof._dr_hab._ Ryszard_Skubisz_UMCS.pdf>.

Sneed, Martha Crockett (2000). Fully Disclosed Yet Merely Descriptive: Intricacies of Training the Patent and Trademark Information Professional. Journal of Library Administration, 29(1), pp. 59-78. https://doi.org/10.1300/J111v29n01_05.

Studziński, Szymon (2016). Nowoczesne sposoby ochrony marki - abstrakcyjne znaki towarowe. Acta Scientifica Academiae Ostroviensis. Sectio A, Nauki Humanistyczne, Społeczne i Techniczne, (8(2)), s. 505-520 [online], [dostęp: 11.11.2019]. Dostępny w WWW: <http:// cejsh.icm.edu.pl/cejsh/element/bwmeta1.element.desklight-90fc1723-d5d9-4575-9b9433b6959c8938/c/Nowoczesne_sposoby_ochrony_504-519.pdf>.

TMview. (b.d.) [online], [dostęp: 29.10.2019]. Dostępny w WWW: <https://www.tmdn.org/ tmview/welcome>.

Trademark Registration. (b.d.) [online], [dostęp: 2.11.2019]. Dostępny w WWW: <https:// www.inta.org/TrademarkBasics/FactSheets/Pages/TrademarkRegistrationFactSheet. aspx>.

Ustawa z dnia 30 czerwca 2000 r. Prawo własności przemysłowej. Dz.U. 2001 nr 49 poz. 508, (2001).

Włoszczyńska, Anna (2008). Rola logo i identyfikacji wizualnej bibliotek narodowych [online], Zagadnienia Informacji Naukowej, (2), s. 63-93 [dostęp: 11.11.2019]. Dostępny w WWW: <http://bbc.uw.edu.pl/dlibra/docmetadata?id=1810\&from=publication\& $>$.

Wojciechowska, Maja; Kamińska, Joanna; Żołędowska-Król, Beata; Jaskowska, Bożena (2019). Leksykon zarzadzania i marketingu w bibliotekoznawstwie. Warszawa: Wydaw. Naukowe i Edukacyjne SBP.

Wojciechowski, Jacek (2006). Stereotyp określa świadomość [online], Przegląd Biblioteczny, (4) [dostęp: 11.11.2019]. Dostępny w WWW: <https://ruj.uj.edu.pl/xmlui/handle/ item $/ 63615$ ? search-result=true\&query=stereotyp+okre $\%$ C5\%9Bla+\%C5\%9Bwiadomo\%C5\%9B\%C4\%87\&current-scope=\&rpp=10\&sort_by=score\&order=desc $>$.

Wójcik, Magdalena (2019). Marka i kształtowanie wizerunku biblioteki. W: Zarządzanie biblioteką. Red. Mai Wojciechowskiej. Warszawa: Wydaw. Naukowe i Edukacyjne SBP.

Zhang, Li (2009). Developing a Systematic Patent Search Training Program. The Journal of Academic Librarianship, 35(3), pp. 260-266. https://doi.org/10.1016/j.acalib.2009.03.010.

Artykut w wersji poprawionej wptyną do Redakcji 15 listopada 2019 r. 
ADAM JACHIMCZYK

Faculty of Journalism, Information and Book Studies

University of Warsaw

e-mail: a.jachimczyk@uw.edu.pl

ORCID: 0000-0003-2917-6926

\title{
LIBRARIES PROTECTING TRADEMARKS AS REFLECTED BY THE CONTENT OF TMview DATABASE
}

\author{
KEYWORDS: Libraries. Trademarks. TMview.
}

ABSTRACT: Thesis/Objective - The aim of the article is to present European library activity in the field of trademark registration. Research methods - The quantity analysis covered countries where trademarks were reported, libraries with the highest number of trademarks reported for registration, reporting year, trademark status, library type, trademark type. Data analyzed were taken from TMview database managed by the European Union Intellectual Property Office. Results/Conclusions - The author identified 380 trademarks reported by libraries from 24 countries - 166 libraries made attempts to register trademarks. Only in 14 countries it was done by national libraries while public libraries did it in 22 countries and research libraries - in 16 countries. Trademark databases may be used to identify products and services offered to libraries and reflect various forms of book and readership promotion in a given area. 